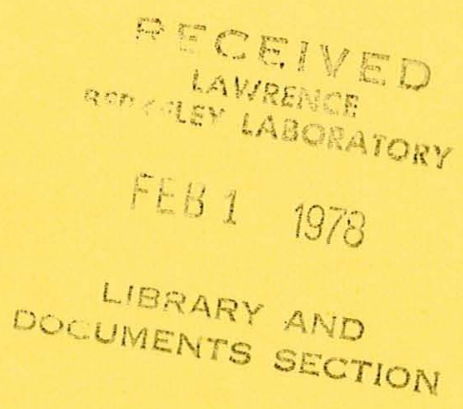

For Reference

Not to be taken from this room

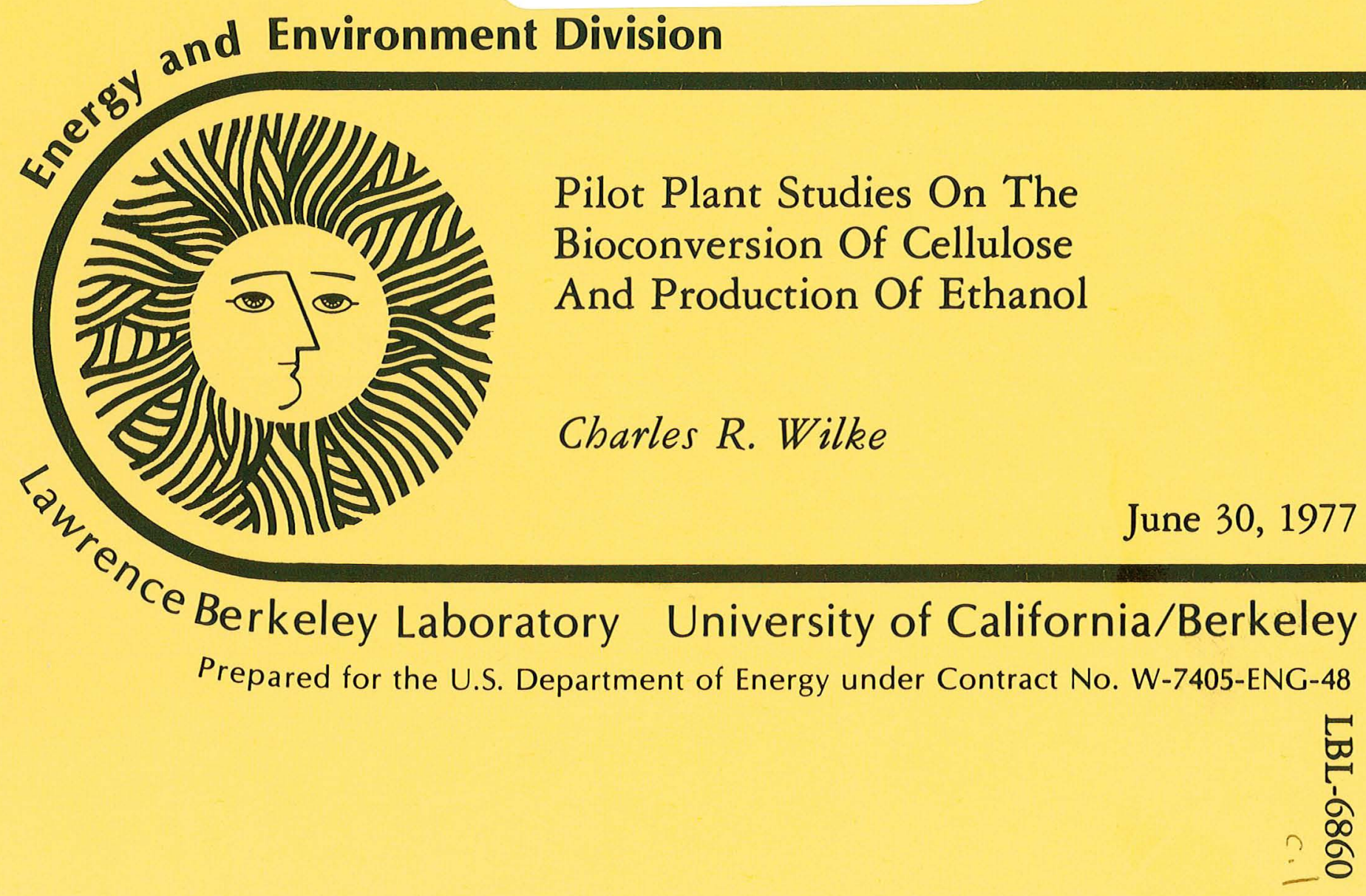




\section{LEGAL NOTICE}

This report was prepared as an account of work sponsored by the United States Government. Neither the United States nor the Department of Energy, nor any of their employees, nor any of their contractors, subcontractors, or their employees, makes any warranty, express or implied, or assumes any legal liability or responsibility for the accuracy, completeness or usefulness of any information, apparatus, product or process disclosed, or represents that its use would not infringe privately owned rights. 


\section{PILOT PLANT STUDIES OF THE BIOCONVERSION OF CELLULOSE \\ AND PRODUCTION OF ETHANOL}

under auspices of

U.S. Energy Research and Development Administration Solar Energy Division--Fuels from Biomass Program

Lawrence Berkeley Laboratory

Charles R. Wilke, Principal Investigator

Report of Work Progress

June 30,1977 



\section{Table of Content}

A. Analysis and Evaluation of Potential Raw Materials.......2

1. Preliminary Pretreatment Studies Using Wheat Straw......2

2. Extraction of Wheat Straw with Alcohol and Water

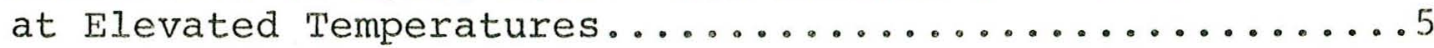

3. Extraction of Ground Wood with Alcohol and Water at

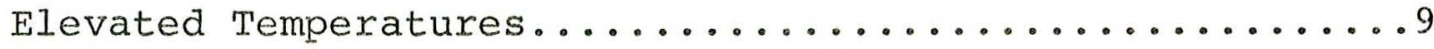

4. Delignification of Newsprint with Ethylene Glycol......13

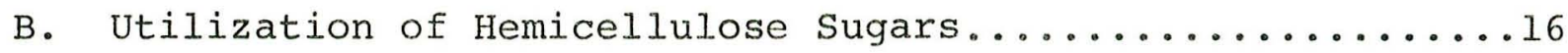

C. Process Design and Economic Studies...................

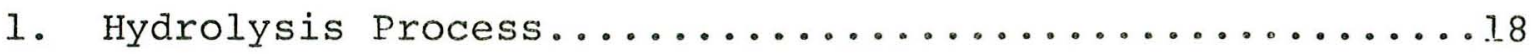

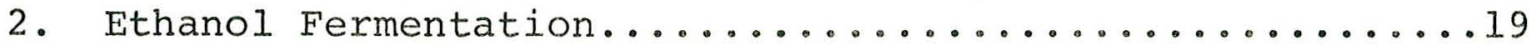

D. Pilot Plant Process Development and Design Studies.......19

1. Cell-Recycle Systems for Cellulase Production.........19

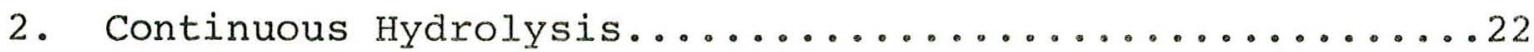

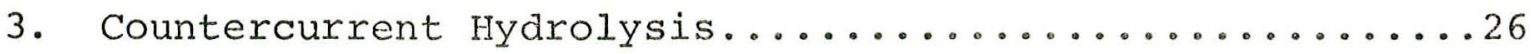

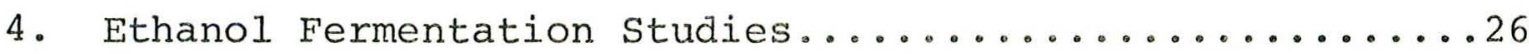

Appended Papers and Reports

1. Process Design Basis for Enzymatic Hydrolysis of Newsprint

2. Computation of the Fraction of Induced Cells in Enzyme Induction systems.

3. Cell Growth and Catecholase Production of Polyporus versicolor in Submerged Cultures.

4. Exponential Growth Kinetics for Polyporus versicolor and Pleurotus ostreatus.

5. Rapid Ethanol Fermentation Using Vacuum and Cell Recycle.

6. Studies on th Enzymatic Hydrolysis of Newsprint. LBL-5950.

7. The Effect of Glucosidase on the Enzymatic Hydrolysis of Cellulose. LBL-4413

8. Decomposition of Lignin and Cellobiose in Relation to the Enzymatic Hydrolysis of Cellulose. LBL-5960.

9. Rapid Ethanol Fermentations Using Vacuum and Cell Recycle. LBL-5261 
10. Process Design and Economic Studies of Alternative Fermentation Methods for the Production of Ethanol. LBL-5963

11. Enzymes and Microorganisms in Food Industry Waste Processing and Conversion to Useful Products: A Review of the Literature.

12. Production of Sugars and Ethanol Based on the Enzymatic Hydrolysis of Cellulose. LBL-6814.

13. Enzymatic Decomposition of Lignin and Cellobiose in Relation to Hydrolysis of Cellulose. NSF report, July $28,1977$. 
This report summarizes briefly the progress over the period of January 31 to June 30,1977 , on those portions of the program primarily under Solar Energy Division sponsorship. Various reports have been issued or are in press which provide a full account of phases of the work which have been completed (see list appended). A listing is appended of the project personnel and topics presently under study in the entire program under funding by ERDA Solar Energy Division, ERDA Division of Physical Research and National Science Foundation/RANN.

A. Analysis and Evaluation of Potential Raw Materials.

1. Preliminary Pretreatment Studies Using Wheat Straw. Since wheat appears to represent a difficult case among the agricultural residues, and is readily available, it was chosen for further study to see if other than alkali treatments would afford delignification and/or improvement in sugar yields in enzyme hydrolyzates.

As seen in table $\mathrm{C}-1$ of the previous progress report, hydrolysis of a 5.0\% suspension consisting of 100 pounds of Wileymilled wheat containing 32.9 pounds of glucan, equivalent to 36.5 pounds of glucose yields 8.9 pounds of glucose in the hydrolyzate. This is a $24.4 \%$ conversion. From table C -3 of the previous progress report it is seen that 15 pounds of glucose and 2.4 pounds of cellobiose are obtained from the acid pretreatment liquor and subsequent enzymatic hydrolysis of the acid treated substrate. This represents a $47.7 \%$ conversion, nearly double the yield from the original wheat. A delignification step was next performed on the wheat straw using the common analytical method 

with sodium chlorite and acetic acid.

The $2 \mathrm{~mm}$ Wiley-milled wheat was first subjected to a benzene-alcohol azeotrope extraction to remove reactive phenolic resins and a hot water extraction to remove soluble inorganic components which also consume chlorine dioxide. An $82.94 \%$ yield of a tan colored solid was obtained with an assay of:

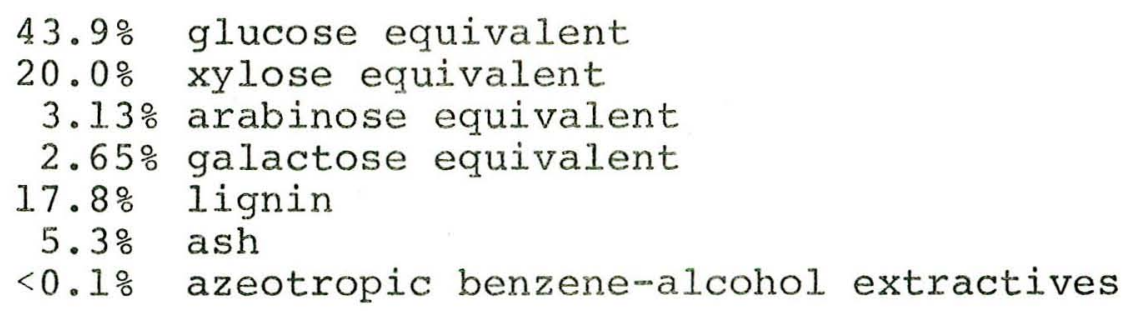

This material was then subjected to the analytical sodium chlorite-acetic acid delignification treatment. A 68.91\% yield of wheat straw based on original material was obtained with the following composition:

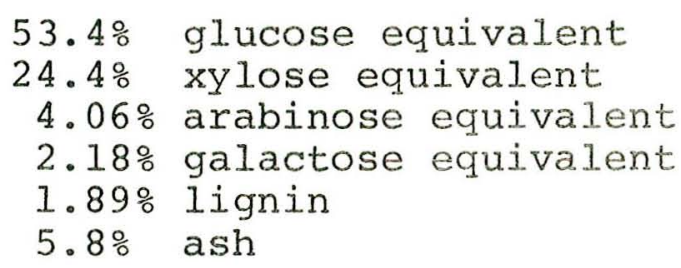

The lignin content was reduced by a factor of about 7.7 relative to the original material. A portion of this material was also ball milled at $3^{\circ} \mathrm{C}$ for 20 hours to 150 mesh $(0.105$ M.M. particles), and both samples were then enzymatically hydrolyzed. The results are shown in table $A-1$. Also included for the comparison are sugar yields from the enzymatic hydrolysis of the original wheat.

It would seem that ball milling, which increases surface area and also causes a decrease in the degree of polymerization of cellulose, rather than delignification, is the predominant factor in 
Enzyme Hydrolysis of 5 wo suspensions of chlorite treated, resin and inorganic pre-extracted wiley milled wheat straw

Basis: 100 lbs. of original wheat straw, containing $36.5 \%$ glucose and $16.9 \%$ xylose equivalents

\begin{tabular}{|c|c|c|c|c|c|}
\hline Substrate & Glucose & Cellobiose & Xylose & $\begin{array}{l}\text { Lignin } \\
\text { Content } \\
\quad(\%)\end{array}$ & $\begin{array}{c}\text { Glucose and Dimer } \\
\text { Conversion } \\
(\%)\end{array}$ \\
\hline $\begin{array}{l}\text { Original wheat } \\
\text { (2mm Particles) }\end{array}$ & 8.9 & & 2.4 & 14.5 & 24.4 \\
\hline $\begin{array}{l}\text { Chlorite treated } \\
\text { wheat }\end{array}$ & 5.4 & 8.1 & 8.8 & 1.9 & 38.2 \\
\hline $\begin{array}{l}\text { Chlorite treated } \\
\text { and ball milled } \\
(0.105 \mathrm{~mm} \text { Particles })\end{array}$ & 9.3 & 14.3 & 12.0 & 1.9 & 66.7 \\
\hline
\end{tabular}


increasing substrate reactivity.

2. Extraction of Wheat Straw with Alcohol and Water at Elevated Temperatures.

Kleinert (1) has reported the results of alcohol and water extraction on various types of wood chips at $185^{\circ} \mathrm{C}$. It was decided to see if this process could be adapted to wheat since alcohol would be readily available.

The $2 \mathrm{~mm}$ Wiley-milled wheat was suspended in $42.5 \mathrm{w} \%$ alcohol. and water (50-50 volume mix of $95 \mathrm{w} \%$ alcohol and water) in a $1: 10$ solids to liquid ratio. The container was a 2-liter stainless steel container (3500 psi burst strength) fitted with a thermocouple well. The amount of suspension used accommodated the 45\% increase in volume that occurs as the temperature increases from room temperature to $185^{\circ} \mathrm{C}$. The mixture was heated to $185^{\circ} \mathrm{C}$ and maintained at this temperature for approximately 1 hour and mixed manually every 10 minutes. The mixture was cooled in an ice bath to approximately $50^{\circ} \mathrm{C}$ and vacuum filtered. The dark brown liquor was kept for analysis and material balance. The solid was washed with warm $50 \mathrm{v}$ o alcohol and water until the washes were a pale yellow and showed insignificant amounts of soluble lignin.

$65.43 \%$ of the original wheat was recovered and the composition was as follows:

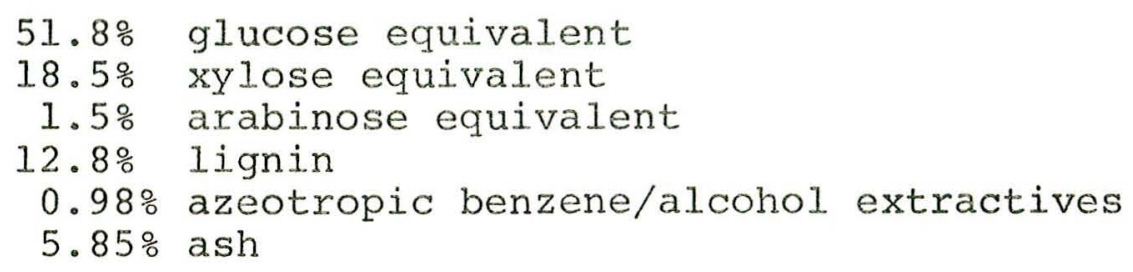

Lignin removal from straw (ca. 40\%) is not as good as that reported for wood ( $90 \%)$. The results of the enzymatic hydrolysis 
of this material are shown in table $A-2$.

The dark brown alcoholic liquor and washes were tested for sugar. Based on 100 pounds of original wheat, 0.9 pounds of glucose, 0.12 pounds of cellobiose, 0.3 pounds of xylose and 6.14 pounds of alcohol soluble liqnin were found. The soluble lignin and carbohydrates were separated by diluting the liquor with an equal volume of water and vacuum evaporating the alochol and water at $45^{\circ} \mathrm{C}$. This was necessary since the fine tan precipitate could be neither vacuum filtered nor centrifuged because the particles were less than $0.22 \mu \mathrm{m}$ in size. In this way, a $31.2 \%$ yield of a dark brown friable solid based on original wheat straw was obtained. This material assayed at 19.7\% Lignin. Enzymatic hydrolysis of 31.2 pounds of this material would yield:

$\begin{array}{cl}1.2 & \text { pounds glucose } \\ 4.7 & \text { pounds xylose } \\ 0.34 & \text { pounds arabinose } \\ 0.28 & \text { pounds mannose } \\ 0.17 & \text { pounds galactose } \\ 0.07 & \text { pounds cellobiose } \\ \sim 2 & \text { pounds soluble lignin }\end{array}$

It appears that the yields of sugars and/or hydrolyzable carbohydrates are quite low in the alcoholic liquor. 99.5\% of alcohol was recovered and it contained 3.3 pounds gluconic and glucuronic acid lactone.

This whole process was repeated using 50 w\% alcohol-water solution, and the reaction temperature was raised to $230^{\circ} \mathrm{C}$ to see if delignification could be better effected. Also, the wheat was extracted with hot water first to remove water soluble components which would represent an additional load on the alcohol extraction. 
The yield on water extraction was $84.9 \%$ and the solid assayed

$$
\begin{aligned}
& 41.9 \% \text { glucose equivalent } \\
& 20.6 \% \text { xylose equivalent } \\
& 3.3 \% \text { arabinose equivalent } \\
& 1.6 .1 \% \text { lignin } \\
& 2.1 \% \text { azeotropic benzene-alcohol extractives } \\
& 6.4 \% \text { ash }
\end{aligned}
$$

The yield of 50 wo alcohol-water extracted wheat at $230^{\circ} \mathrm{C}$ was $40.06 \%$ based on original material and the solid assayed

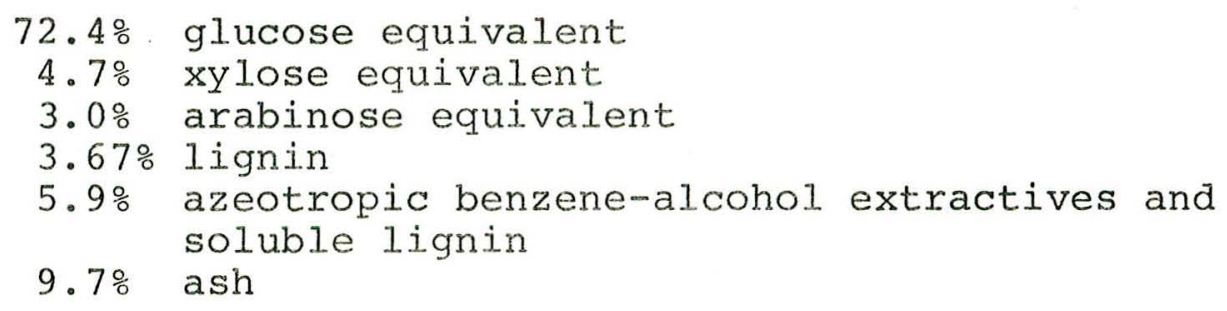

As can be seen there is a significant decrease in lignin content. The results of enzymatic hydrolysis of this material are also shown in table A-2. As before, the deep brown alcoholic liquor was diluted with an equal volume of water and then the alcohol and water were separated from the precipitate by vacuum evaporation at $45^{\circ} \mathrm{C}$. There was obtained a dark brown friable powder in a 31.7\% yjeld, based on original material. It contained $51.0 \%$ lignin, and $99.1 \%$ of the alcohol was recovered. Enzymatic hydrolysis of a 5 wo suspension of this material on a 31.73 pound basis would yield 1.3 pounds of glucose, 0.14 pounds of xylose and 0.1 pounds of arabinose. As before, the yields of sugars in the alcohol liquor are quite low, contrary to what has been reported with wood.

It would seem from the results listed in table A-2 that delignification does not greatly improve sugar yields from wheat. However, delignification is still very desirable for the induction stage of the Berkeley Process. 
Table $A-2$

Enzyme Hydrolysis of 5 wo Suspensions of Alcohol Treated Wheat

Basis: 100 Ibs of original wheat straw containing $36.5 \%$ glucose equivalent,

$16.9 \%$ xylose equivalent

\begin{tabular}{|c|c|c|c|c|c|}
\hline Substrate & Glucose & Cellobiose & Xylose & $\begin{array}{l}\text { Substrate } \\
\text { Lignin } \\
\quad(\%)\end{array}$ & $\begin{array}{l}\text { Total Glucose and } \\
\text { Dimer Conversion } \\
\left(\frac{\%}{\%}\right)\end{array}$ \\
\hline $\begin{array}{l}\text { Original wheat } \\
\text { (2MM Particles) }\end{array}$ & 8.9 & - & 2.4 & 14.5 & 24.4 \\
\hline $\begin{array}{l}42.5 \text { w\% Alcohol, } \\
\text { Extracted at } 185^{\circ} \mathrm{C}\end{array}$ & 11.9 & 1.2 & 9.3 & 12.8 & 39.6 \\
\hline $\begin{array}{l}\text { Alcoholic Liquor } \\
\text { Residue }\end{array}$ & 1.2 & 0.07 & 4.7 & 19.7 & \\
\hline $\begin{array}{l}50 \text { w\% Alcohol } \\
\text { Extracted at } 230^{\circ} \mathrm{C}\end{array}$ & 9.4 & 2.7 & 0.71 & 3.67 & \\
\hline $\begin{array}{l}\text { Residue from } \\
\text { Alcohol Liquor }\end{array}$ & 1.3 & - & 0.14 & 51.0 & \\
\hline
\end{tabular}


3. Extraction of Ground Wood with Alcohol and water at Elevated Temperatures

The alcohol/water extraction was repeated using ground wood obtained from the Boise Cascade Company. This material is the source of Wall street Journal stock paper on the West Coast. The ground wood is hypochlorite bleached and is a mixture of $60 \%$ western hemlock, 25\% white fir and $15 \%$ western spruce. It assayed thus:

$\begin{aligned} 44.4 \% & \text { glucose equivalent } \\ 13.6 \% & \text { mannose equivalent } \\ 1.2 \% & \text { galactose equivalent } \\ 4.3 \% & \text { xylose equivalent } \\ 1.6 \% & \text { arabinose equivalent } \\ 31.0 \% & \text { lignin } \\ 1.8 \% & \text { azeotropic benzene-alcohol } \\ 0.2 \% & \text { ash }\end{aligned}$

The ground wood was acid pretreated as previously described. A $79.3 \%$ yield of a pale tan friable product with the following composition was obtained:

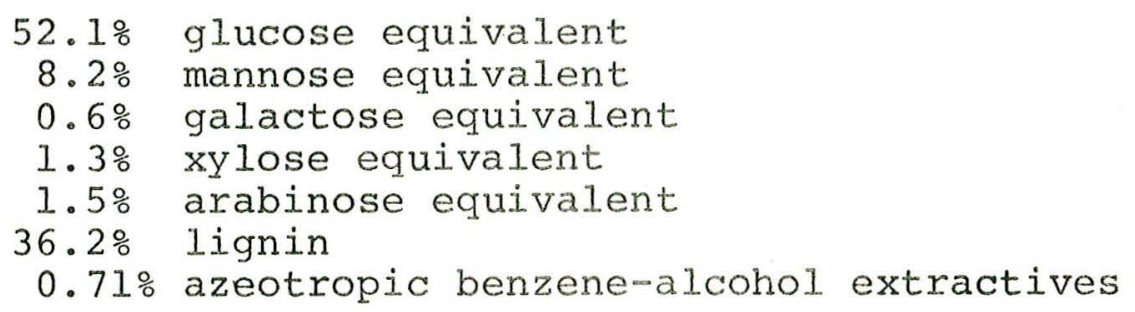

As can be seen, the galactose, mannose, arabinose and xylose have been reduced considerably, and the glucose was reduced by about $7 \%$. Also, based on a material balance, 2.3 1bs./100 or approximately $7.4 \%$ of the lignin was acid soluble. The sugars obtained from the acid liquor, as well as the sugars obtained by enzymatic hydrolysis of the acid treated substrate, are listed in table A-3.

The acid treated substrate was then subjected to an extraction with $50 \mathrm{w}$ \% alcohol-water solution at $225^{\circ} \mathrm{C}$ for one hour. As 


\section{Table A-3}

Yield of Sugars from Enzyme Hydrolysis of Acid Treated wood and Acid Liquor

Basis: 100 lbs. of original material containing $44.4 \%$ glucose equivalent

\begin{tabular}{|l|c|c|c|c|c|c|}
\hline Material & Glucose & Cellobiose & Xylose & Arabinose & Mannose & $\begin{array}{c}\text { Tother } \\
\text { Dimer } \begin{array}{c}\text { Glucose and } \\
\text { (\%) }\end{array}\end{array}$ \\
\hline $\begin{array}{l}\text { Original Wood } \\
\text { (2MM Particles) }\end{array}$ & 8.0 & 1.3 & 0.44 & 0.1 & 2.3 & 21.1 \\
\hline $\begin{array}{l}\text { Acid Treated } \\
\text { Wood }\end{array}$ & 8.1 & 0.5 & 0.1 & - & 1.5 & $\begin{array}{c}0.1 \\
\text { Galactose }\end{array}$ \\
\hline $\begin{array}{l}\text { Acid Liquor } \\
\text { Only }\end{array}$ & 1.2 & 0.6 & 2.3 & 1.2 & 6.4 & $\begin{array}{c}1.5 \\
\text { Galactose }\end{array}$ \\
\hline
\end{tabular}


described previously, the alcoholic liquor was separated from the treated solid. The yield of sugars obtained by enzymatic hydrolysis of this liquor residue is shown in table $A-4$.

There was obtained an average yield of $46.6 \%$ of alcohol extracted material based on the original wood. The composition was:

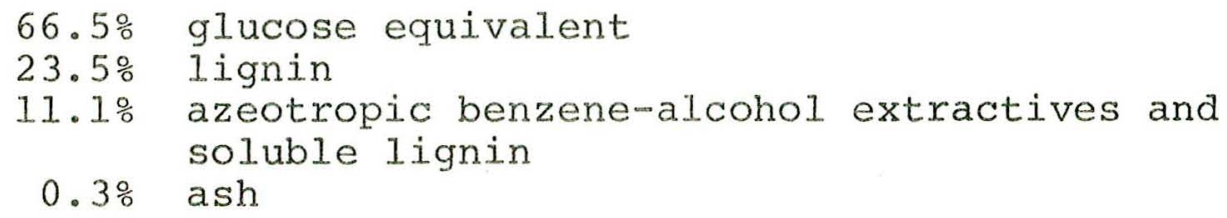

Based on a material balance of the original lignin there was a total of 20.1 pounds of lignin/100 removed by acid pretreatment and alcohol extraction. The results of enzymatic hydrolysis of this alcohol extracted wood are also listed in table $A-4$.

It is quite obvious that in the case of this ground wood, the alcohol extraction does not delignify sufficiently under these conditions. Also, there is an approximate 50\% decrease in glucose yield.

To see if the glucose yield could be improved, the $225^{\circ} \mathrm{C}$ alcohol extracted wood was subjected to the analytical chlorite delignification procedure. There was obtained a white product with a 31.3\% yield, based on original wood, which assayed

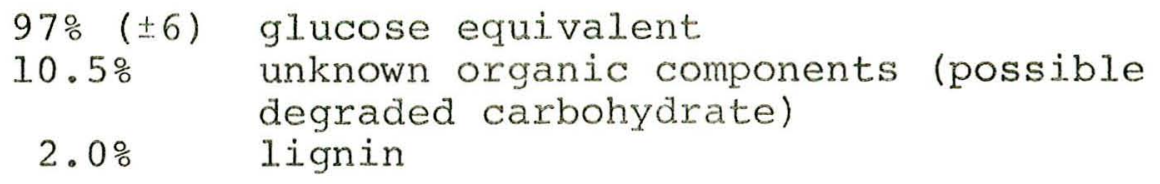

This material was enzymatically hydrolyzed at 5\% w suspension and the results were expressed as the sugar yields from 31.27 pounds of the material hydrolyzed. The results are listed in table $A-4$. The glucose and dimer conversion nearly equals the value for 
Table $A-4$

Enzyme Hydrolysis of Alcohol Extracted, Acid Pretreated Ground Wood

Basis: 100 lbs of original ground wood

containing $44.4 \%$ glucose equivalent

\begin{tabular}{|l|c|c|c|c|c|c|}
\hline Material & Glucose & Cellobiose & Xylose & Other & $\begin{array}{l}\text { Substrate } \\
\text { Lignin } \\
(\%)\end{array}$ & $\begin{array}{l}\text { Glucose \& Dimer } \\
\text { Conversion } \\
(\%)\end{array}$ \\
\hline $\begin{array}{l}\text { Alcohol Extracted } \\
\text { Wood }\end{array}$ & 4.8 & 0.54 & - & - & 23.5 & 12.5 \\
\hline $\begin{array}{l}\text { Alcohol Liquor } \\
\text { Residue }\end{array}$ & 0.2 & - & 0.05 & $\begin{array}{l}0.1 \text { mannose } \\
0.05 \text { arabinose }\end{array}$ & 73.7 & \\
\hline $\begin{array}{l}\text { Chlorite Treated } \\
\text { Alcohol Extracted } \\
\text { Wood }\end{array}$ & 7.8 & 1.3 & 0.06 & & & \\
\hline
\end{tabular}


the original wood of 21 \% conversion even though the substrate lignin content has been decreased to $2 \%$

To check the discrepancy with the reported results on this wood (2) the author's substrate containing $8.2 \%$ lignin was again enzymatically hydrolyzed. The 40-houx sugar yield as measured colorimetrically with the D.N.S. method was 26.8 grams of glucose per liter and not the 41 obtained previously. The sugar composition of the hydrolyzate obtained was $52.4 \%$ glucose, $39.2 \%$ cellobiose, and $6.7 \%$ xylose, determined chromatographically. The D.N.S. method is nearly 33\% too high because of this sugar distribution.

The experiments on delignification and hydrolysis of wood will be repeated to confirm the apparently low sugar yields obtained. 4. Delignification of Newsprint with Ethylene Glycol.

A short study was performed on newsprint to investigate delignification and possible increase in sugar yields using ethylene glycol as has been reported for wood (3). The process involves delignification by a mild acid depolymerization reaction followed by solvation of the lignin with a recoverable solvent, rather than solution alone.

A solution of 0.00765 molar sulfuric acid in ethylene glycol was refluxed at $197^{\circ} \mathrm{C}$. The $2 \mathrm{~mm}$ Wiley-milled newsprint which had been acid pretreated $\left(93.8 \%\right.$ dry) was quickly added forming a $4.7 \mathrm{w} / \mathrm{w}_{\%}$ suspension. The reflux temperature decreased to the desired $180^{\circ} \mathrm{C}$ (due to the moisture content of the newsprint), and the suspension was refluxed and magnetically stirred for 30 minutes. The dark brown mixture was cooled to $\sim 80^{\circ} \mathrm{C}$ and vacuum filtered. The sugars in the liquor and washes were tracked colorimetrically and quantitatively by G.L.C. The residue required six portions of $\sim 150^{\circ} \mathrm{C}$ 
ethylene glycol washes to reduce the sugars in the last wash to less than 1\% of the liquor sugar concentration. Each wash was also tested for soluble lignin. It appears that the soluble lignin is removed at essentially the same rate as the occluded sugars.

There was obtained an average $41.1 \%$ yield, based on the acid pretreated newsprint which compares with the $41.1,40.9,40.5 \%$ reported for wood (3). The yield based on the original newsprint would be $34.75 \%$ and assayed as follows:

$$
\begin{aligned}
& 97 \% \\
& 4.72 \%( \pm .5) \text { lignin }
\end{aligned}
$$

For comparison the original newsprint contains:

$$
\begin{aligned}
& 65.5 \% \text { glucose equivalent } \\
& 15.6 \% \text { mannose equivalent } \\
& 4.6 \% \text { xylose equivalent } \\
& 0.5 \% \text { arabinose equivalent } \\
& 21.0 \% \text { lignin } \\
& 2.5 \% \text { azeotropic benzene/alcohol extractives } \\
& 0.35 \% \text { ash }
\end{aligned}
$$

Upon enzymatic hydrolysis of a 5 wo suspension of the glycol extracted-acid pretreated newsprint there was obtained a $48 \%$ conversion of available glucan. The results of these experiments are shown in table $A-5$.

It appears that acid extraction of the newsprint offers the advantage of separating over half of the mannan and xylan from the glucan, but at the expense of the glucose ultimately obtained by enzymatic hydrolysis of acid pretreated cake. With the ethylene glycol extraction, likewise there is a decrease of glucose obtained in the enzymatic hydrolyzate. However, the yield of 3.1 glucose in the acid liquor, 28.6 in the glycol liquor and the 16.2 in the enzymatic hydrolyzate of the glucol treated residue gives a 
Table A-5

BASIS: 100 Ibs. OF ORIGINAL WILEY-MILLED NEWSPRINT

\begin{tabular}{|c|c|c|c|c|c|c|}
\hline $\begin{array}{l}\text { Material Form } \\
\text { and Operation }\end{array}$ & Glucose & $\begin{array}{l}\text { Polymeric } \\
\text { Glucose }\end{array}$ & Xylose* & Arabinose* & Mannose & $\begin{array}{l}\text { Soluble } \\
\text { Lignin }\end{array}$ \\
\hline $\begin{array}{c}\text { Enzyme hydrolysis of } \\
\text { original material }\end{array}$ & 20.8 & 4.0 & 1.8 & 0.16 & 3.8 & -- \\
\hline $\begin{array}{l}\text { Acid extraction liquor } \\
\text { of original material }\end{array}$ & 3.1 & $<0.1$ & 2.2 & 0.1 & 9.8 & -- \\
\hline $\begin{array}{l}\text { Enzyme hydrolysis of } \\
\text { acid extracted } \\
\text { material }\end{array}$ & 9.8 & 0.8 & 0.7 & 0.08 & 2.0 & -- \\
\hline $\begin{array}{l}\text { Ethylene glycol liquor } \\
\text { of acid treated } \\
\text { material }\end{array}$ & 28.6 & -- & 1.3 & 0.25 & 4.8 & 20.0 \\
\hline $\begin{array}{l}\text { Enzyme hydrolysis of } \\
\text { glycol treated } \\
\text { material }\end{array}$ & 16.2 & -- & 0.41 & -- & 0.40 & $\sim 0.1$ \\
\hline $\begin{array}{l}\text { Acid treatment and } \\
\text { enzyme hydrolysis }\end{array}$ & 12.9 & $\begin{array}{c}\text { AL YIELD } \\
0.85\end{array}$ & SUMMARY & 0.18 & 11.8 & -- \\
\hline $\begin{array}{l}\text { Acid treatment, } \\
\text { glycol treatment } \\
\text { and enzyme hydrolysis }\end{array}$ & 48. & -- & 3.9 & 0.35 & 15 . & 20.0 \\
\hline
\end{tabular}

*They contain small amounts of polymeric pentoses. 
total of 47.9 lbs of glucose. This represents overall a $73 \%$ conversion and looks attractive. Also the hydrolyzate contains less than 2.5\% each of xylose and mannose, a desirable feature.

\section{B. Utilization of Hemicellulose Sugars.}

Hemicelluloses comprise a significant fraction of cellulosic materials. Since xylose is the major component of most hemicellulose sugax mixtures, the conversion of this sugar to ethanol by the fungus Fusarium oxysporum is being studied. A good deal of progress has been made in understanding this fermentation since the last report was completed. Specifically:

The temperature optimum for growth of the fungus and production of ethanol has been established $\left(28-30^{\circ} \mathrm{C}\right)$.

A complete mass balance for the fermentation has been run with $94 \%$ of the xylose carbon accounted for (TableB-I). The ethanol yield factor was found to be $0.41 \mathrm{~g} / \mathrm{g}$ xylose fermented, not 0.35 as stated in the previous report.

It was noted that batch fermentations ceased before the xylose was completely utilized. Separate studies indicated that neither ethanol build-up nor culture pH change could account for this effect. Further experiments indicated that nutrient depletion is also not responsible for the observed effect. Preliminary studies suggest that an inhibitor may be produced during growth.

Continuous fermentations have been run with a cell-recycle system. The ethanol productivity of the culture was approximately double that found in continuous cultures without recycle $10.07 \mathrm{~g}$ ethanol/L-hr vs. $0.04 \mathrm{~g}$ ethanol/L-hr), although it is still considered to be too low. Unlike the batch culture system, in 
TABLE $B-1$

Overall Yield Factors

\begin{tabular}{lc}
\hline Component & Yield Factor gm/gm Xylose \\
\hline Cell Mass & 0.12 \\
Ethanol & 0.41 \\
Carbon Dioxide & 0.32 \\
Acetic Acid & 0.04 \\
\hline
\end{tabular}


continuous cultures all the xylose is fermented.

Finally, batch fermentations have been conducted using crude hemicellulose obtained by dilute acid extraction of straw. The fermentations were carried out in the acid extract liquor after appropriate $\mathrm{pH}$ adjustment and the addition of growth nutrients. Acid extracted glucose, xylose and arabinose were fermented to ethanol under these conditions.

The research so far has revealed several problems: 1) The growth rate of the organism and the rate of ethanol production axe too low, 2) A growth inhibitor appears to be produced in batch cultures, 3) The continuous culture cell-recycle system tends to plug with cells.

To attack these problems, future research will be focused on the following approaches: The organism will be grown anaerobically in a number of new media to see if one can be identified that allows faster growth and complete xylose fermentation. Growth inhibition problems may not be encountered in a different medium. If this problem is encountered, or if the original medium proves superior to the others tested, the nature of the inhibitor will be determined, and ways will be devised to remove it.

It is also intended to continue the work on continuous anaerobic culture with cell-recycle. The cell-recycle system will be modified to eliminate the plugging problem.

\section{Process Design and Economic Studies}

1. Hydrolysis Process.

No new design studies have been made pending the outcome of laboratory work on the process steps. A paper "Process Design 
Basis for Enzymatic Hydrolysis of Newsprint" based on report LBL-5267 has been published (4). This paper may be useful for others who might wish to assess the work or make comparisons with alternate schemes under comparable design bases.

\section{Ethanol Fermentation.}

A revised economic study of the alternative fermentation process has been completed (LBL-5963, copy appended) for the processing of molasses containing 50\% sugar to produce 78,000 gallons per day of $95 \%$ ethanol.

In this report a cell-recycle and vacuum fermentation process is described for the continuous production of ethanol. Preliminary process design studies are employed to make an economic comparison of these alternative fermentation schemes with continuous and batch fermentation technologies. Designs are based on a production capacity of 78,000 gallons per day of 95\% ethanol employing molasses as the fermentation substrate. The studies indicate that a 57\% reduction in fixed capital investment is realized by continuous rather than batch operation. Further decreases in required capital investment of $68 \%$ and $71 \%$ over batch fermentation were obtained for cell recycle and vacuum operation, respectively. However, ethanol production costs were dominated by the cost of molasses, representing over $75 \%$ of the total manufacturing cost. But, when a reasonable yeast by-product credit was assumed, the net production cost for $95 \%$ ethanol was established at 82.3 and 80.6 cent/gal., for the cell-recycle and vacuum processes, respectively.

D. Pilot Plant Process Development and Design Studies.

1. Cell-Recycle system for Cellulase Production. Earlier studies of this method employed a single stage 
fermentor with a settler and a centrifugal separator attached to permit recycle.

Recent work was focused on the development of a multistage fermentor with a cell-recycle system. Two-stage and three-stage systems were tested. Maximum enzyme productivity thus far has been obtained with the two-stage system.

In the two-stage system, the first stage was operated on solka Floc as the carbon source followed by a single induction stage to which cell recycle was directed. The temperature was maintained at $30^{\circ} \mathrm{C}$, and the $\mathrm{pH}$ was 4.8 for both stages. The data obtained during a five-week experimental run indicate that optimum enzyme productivity occurred at an overall dilution rate of $0.029 \mathrm{hr}^{-1}$ with product enzyme concentration of 3.7 FPA. This productivity is compared with that of previous experiments in table $D^{-1}$. The two-stage process shows an average $30 \%$ increase over the single stage with recycle and the single stage with recycle shows a $70 \%$ increase over the single-stage fermentor without cell recycle. The single stage without recycle, however, shows a higher specific productivity over the system with recycle. This indicates that full benefit is not bejng obtained from increased cell density.

Resolving this problem is part of the current effort in enzyme production. The program includes determining the optimum temperature, $\mathrm{pH}$ and substrate concentration in the respective stages for growth and induction and the relationship between cell density and enzyme productivity. Work is also in progress on the development of a kinetic model for cell growth and enzyme production in order to analyze and optimize the process. 
Table $D-1$

Comparison of Enzyme Productivities

\begin{tabular}{|c|c|c|c|c|c|c|}
\hline $\begin{array}{l}\text { FERMENTATION } \\
\text { SYSTEM }\end{array}$ & $\begin{array}{c}\mathrm{D} \\
(1 / \mathrm{HR})\end{array}$ & $\begin{array}{l}S_{R} \\
(G / L)\end{array}$ & $\mathrm{FPA}^{1}$ & $\begin{array}{l}\text { PRODUCTIVITY } \\
(I . U / M I-D A Y)\end{array}$ & $\begin{array}{c}\text { CEII } \\
\text { DENSITY } \\
(G / L)\end{array}$ & $\begin{array}{c}\text { SPECIFIC } \\
\text { PRODUCTIVITY } \\
\text { (I.U/MG-DAY) }\end{array}$ \\
\hline $\begin{array}{l}\text { Single Stage } \\
\text { No recycle }\end{array}$ & $\begin{array}{l}0.020 \\
0.030 \\
0.043 \\
0.053 \\
0.063 \\
0.073 \\
0.093 \\
0.03 \\
0.04 \\
0.06\end{array}$ & $\begin{array}{r}7.5 \\
7.5 \\
7.5 \\
7.5 \\
7.5 \\
7.5 \\
7.5 \\
15.0 \\
15.0 \\
15.0\end{array}$ & $\begin{array}{l}2.7 \\
1.9 \\
1.6 \\
1.50 \\
1.25 \\
0.85 \\
0.20 \\
1.4 \\
0.8 \\
0.7\end{array}$ & $\begin{array}{l}0.192 \\
0.169 \\
0.198 \\
0.22 \\
0.21 \\
0.15 \\
0.035 \\
0.113 \\
0.075 \\
0.10\end{array}$ & $\begin{array}{l}2.3 \\
2.0 \\
2.2 \\
2.0 \\
2.1 \\
2.0 \\
\\
4.0 \\
3.7 \\
3.0\end{array}$ & $\begin{array}{l}0.084 \\
0.085 \\
0.09 \\
0.11 \\
0.10 \\
0.075 \\
0.028 \\
0.020 \\
0.033\end{array}$ \\
\hline $\begin{array}{l}\text { Two stage } \\
\text { No Recycle }\end{array}$ & $\begin{array}{l}0.02 \\
0.03\end{array}$ & $\begin{array}{l}15.0 \\
15.0\end{array}$ & $\begin{array}{l}2.5 \\
2.0\end{array}$ & $\begin{array}{l}0.17 \\
0.18\end{array}$ & $\begin{array}{l}4.6 \\
3.9\end{array}$ & $\begin{array}{l}0.037 \\
0.046\end{array}$ \\
\hline $\begin{array}{l}\text { Single stage } \\
\text { With Recycle }\end{array}$ & $\begin{array}{l}0.02 \\
0.02 \\
0.03 \\
0.032 \\
0.038\end{array}$ & $\begin{array}{l}10 \\
7.5 \\
5 \\
5 \\
5\end{array}$ & $\begin{array}{l}3.7 \\
3.61 \\
2.6 \\
3.2 \\
1.4\end{array}$ & $\begin{array}{l}0.32 \\
0.30 \\
0.27 \\
0.40 \\
0.14\end{array}$ & $\begin{array}{r}7.0 \\
6.9 \\
10.0 \\
8.5 \\
9.0\end{array}$ & $\begin{array}{l}0.046 \\
0.043 \\
0.027 \\
0.047 \\
0.016\end{array}$ \\
\hline $\begin{array}{l}\text { Two Stage } \\
\text { With Recycle }\end{array}$ & $\begin{array}{l}0.021 \\
0.029 \\
0.029 \\
0.029 \\
0.034 \\
\end{array}$ & $\begin{array}{l}10 \\
10 \\
7.5 \\
5 \\
5\end{array}$ & $\begin{array}{l}4.25 \\
3.7 \\
3.7 \\
3.45 \\
2.9 \\
\end{array}$ & $\begin{array}{l}0.43 \\
0.46 \\
0.46 \\
0.41 \\
0.37\end{array}$ & $\begin{array}{l}5.0 \\
8.7 \\
7.0 \\
5.8 \\
6.3\end{array}$ & $\begin{array}{l}0.086 \\
0.053 \\
0.066 \\
0.070 \\
0.058\end{array}$ \\
\hline $\begin{array}{l}\text { Three Stage } \\
\text { With Recycle }\end{array}$ & 0.022 & 10 & 3.8 & 0.36 & 4.5 & 0.080 \\
\hline
\end{tabular}

\footnotetext{
$I_{\text {FPA }}=$ Filter Paper Activity
} 


\section{Continuous Hydrolysis.}

The continuous enzymatic hydrolysis of cellulose has been successfully carried out in single and multistage constant stirming tank reactors (CSTR). Two mm Wiley-milled Wall street Journal was chosen as the substrate. Preweighed newsprint was evenly distributed on a belt conveyer, and then continuously carried to the reactor. Different batches of cellulase filtrate solution produced by Trichoderma viride QM 9414 were adjusted to FPA 3.6 and used throughout this work. Enzyme solution with $0.01 \%$ methiolate was fed into the reactor continuously by a sigma motor pump. This separate solid and liquid feeding system has worked out satisfactorily. The working volume in the reactor of each stage was kept constant by a liquid level controlling device. Solenoid valves connected to the level controller regulated the effluent flow of each stage to the next stage. The hydrolysis temperature was controlled by recixculating water around the jacketed reactor from a $45^{\circ} \mathrm{C}$ water bath.

A batch hydrolysis was run at first in each stage, and then the stages were connected to form a continuous process. Samples were taken at five-hour intervals until the glucose concentration in each reactor reached steady-state. Sugar levels were analyzed by high pressure liquid chromatography. The results of each of the batch and continuous runs are shown in able $\mathrm{D}-2$

Theoretical calculations based on the batch hydrolysis results indicate that, at 30 hours mean residence time, the glucose concentration for single stage CSTR should be $75 \%$ of that for 30 hours batch hydrolysis. After five stages of CSTR, sugar level 
ENZYMAIIC HYDROLYSIS OF 5\% $(w / w)$ NEWSPRIITI

\begin{tabular}{|c|c|c|c|c|c|c|c|c|}
\hline Mean Resident Time & \multicolumn{3}{|c|}{$\tau=20$ hrs. } & \multicolumn{2}{|c|}{$\tau=30 \mathrm{hrs}$} & \multicolumn{3}{|c|}{$\tau=40 \mathrm{hrs}}$. \\
\hline Sugar $(g / l)$ & glucose & cellobiose & xylose & \multicolumn{2}{|c|}{ glucose cellobiose xylose } & glucose & cellobiose & xylose \\
\hline Batch & 6.90 & 2.35 & 0.75 & 2.02 & 0.78 & 9.8 & 1.86 & 0.87 \\
\hline Continuous & 5.66 & 2.48 & 0.68 & 2.29 & 0.75 & 7.78 & 2.18 & 0.8 \\
\hline 3. 2-Stages CSTR & & & & & & & & \\
\hline Mean Residence Time & \multicolumn{3}{|c|}{$\tau=20$ hrs. } & \multicolumn{2}{|c|}{$\tau=30$ hrs. } & \multicolumn{3}{|c|}{$\tau=40$ hrs. } \\
\hline Sugar $(g / 1)$ & glucose & cellobiose & xylose & glucose cellobi & xylose & glucose & cellobiose & xylose \\
\hline Batch & 7.48 & 2.48 & 0.74 & 2.16 & 0.78 & 10.1 & 1.71 & 0.88 \\
\hline Continuous & 6.85 & 2.45 & 0.71 & $8.05 \quad 2.41$ & 0.76 & 8.88 & 2.35 & 0.84 \\
\hline C. 3-Stages CSTR & & & & & & & & \\
\hline $\begin{array}{l}\text { Mean Residence Time } \\
\text { Sugar }(g / 1)\end{array}$ & glucose & $\begin{array}{l}\tau=15 \text { hrs } \\
\text { cellobiose }\end{array}$ & xylose & $\begin{array}{r}\tau=30 \mathrm{~h} \\
\text { glucose cellobi }\end{array}$ & xylose & glucose & $\begin{array}{l}\tau=45 \text { hrs. } \\
\text { cellobiose }\end{array}$ & xylose \\
\hline Batch & 6.6 & 2.18 & 0.68 & 1.97 & 0.79 & 10.0 & 1.62 & 0.81 \\
\hline Continuous & 6.3 & 2.15 & 0.66 & 2.09 & 0.75 & 9.48 & 1.77 & 0.77 \\
\hline
\end{tabular}

g/1 - gram per liter 
would approach $95 \%$ of the batch value. The continuous hydrolysis results show that the glucose concentration ratio of CSTR vs. batch also improves as the stage number increases. At 30 hours mean residence time, this ratio is $80 \%$ for single stage, $90 \%$ for two-stages and 95\% for three-stages. Thus for CSTR-in-series, theory and experiment are in reasonably close agreement. Also, in the continuous enzymatic hydrolysis process, multistage CSTR's will approach a plug flow reactor.

Since the working system is just a simulation of the ideal CSTR-in-series, the residence time distribution of the fluid has been tested. Ammonium chloride was used as a tracer. After a pulse input of the trace, samples were taken from the exit position in each tank. The output concentration of ammonium chloride was analyzed by an orion ammonia electrode, model 95-10. The age distribution E curve was plotted and compared with the theoretical E curve. Both are in reasonable agreement with each other within experimental accuracy.

The recoverable cellulase activities in batch and continuous processes have been determined. The supernatants of the hydrolyzate were precipitated with 3 volumes of acetone and then redissolved in $0.05 \mathrm{M}$ acetate buffer. Filter papex and $\mathrm{C}_{\mathrm{x}}$ activities were analyzed. According to these results (shown in Table D-3), the amount of soluble cellulase left in the multistage, continuous hydrolysis is close to that of the batch hydrolysis.

Product inhibition experiments in the continuous hydrolysis process will be done next. Concurrently, the M.S. thesis for this work will be in preparation. 
Table D-3

Soluble Cellulase Activity After Hydrolysis

\begin{tabular}{|c|c|c|c|c|}
\hline & & $c_{x}$ Activity & FPA & \% Recoverable FPA \\
\hline \multirow{3}{*}{$\begin{array}{l}\text { ENZYME } \\
\text { CONTROL }\end{array}$} & Type & & \multirow[b]{2}{*}{3.60} & \\
\hline & Original & 2.74 & & \\
\hline & Precipitated Solution & 2.5 & 3.30 & 100 \\
\hline \multirow{4}{*}{ Batch } & Reaction Time & & & \multirow[b]{2}{*}{46.4} \\
\hline & 15 hours & 1.64 & 1.53 & \\
\hline & 30 hours & 1.5 & 3. 28 & 38.8 \\
\hline & 45 hours & 1.42 & 1.11 & 33.6 \\
\hline \multirow{4}{*}{ 3-Stages CSTR } & Residence Time & \multirow[b]{2}{*}{1.8} & \multirow[b]{2}{*}{1.57} & \multirow[b]{2}{*}{47.6} \\
\hline & 15 hours & & & \\
\hline & 30 hours & 1.52 & 1.17 & 35.5 \\
\hline & 45 hours & 1.34 & 1.09 & 33.0 \\
\hline
\end{tabular}


3. Countercurrent Hydrolysis.

Efforts are still in progress to develop a successful apparatus for conducting countercurrent movement of cellulose against enzyme solution. Small scale screw conveyors were unoperable. Tests are being performed to determine the feasibility of using a gravitational settling system between stages.

4. Ethanol Fermentation Studies.

Effort during this period has beem mainly applied to a study of the simultaneous enzymatic hydrolysis and fermentation of cellulose.

Previous studies in this laboratory have shown that hydrolysis of cellulose with T. viride cellulase will proceed satisfactorly in solutions containing as much as 5\% ethanol. It seems reasonable to expect, therefore, that it would be possible to grow a yeast culture in suspensions of cellulose in cellulase solution and produce ethanol directly from cellulose. The method would offer the practical advantage of not requiring separate production of sugar. A further expected benefit would be the enhancement of the enzymatic hydrolysis step by removing glucose as it is formed and thereby avoiding glucose inhibition of the enzymatic process.

Experiments were conducted in batch reactors with approximately 5\% suspensions of Solka Floc (cellulose) plus $\underline{T}$. viride cellulase in the presence and absence of yeast (Saccharomyces cerevisiae ATCC 4126). It was found that the hydrolysis proceeds more rapidly in the presence of yeast, and that the production of cellobiose is reduced in favor of a corresponding greater glucose production and ethanol yield. At $45^{\circ} \mathrm{C}$ with an enzyme activity of $3.8 \mathrm{FPA}$ in the 
presence of yeast, the conversion of Solka Floc to ethanol was approximately $60 \%$ in 40 hours and $80 \%$ in 100 hours. In the absence of yeast the corresponding conversions were $32 \%$ and $53 \%$, respectively.

This work will be continued to assess, in a preliminary way, whether or not it might be more economical to conduct the hydrolysis and fermentation operations separately or together, including the possibility of conducting the combined operation under vacuum.

The vacuum fermentation process for ethanol is undergoing further economic assessment for an operating configuration in which the fermentor is operated under atmospheric pressure in conjunction with a vacuum stripping vessel through which the fermentor contents are recycled to accomplish ethanol removal. A report on this study will be completed shortly. The concept looks favorable at this point. An experimental test of the concept will be made if the economic assessment is favorable.

Work is still in progress to optimize the fermentation medium with particular emphasis on the yeast extract requirement and on the possibility of generating most of the yeast extract requirement from the cells produced in the fermentation. 


\section{References}

1. Kleinert, T.N., Tappi, 57(8), 99 (1974)

2. Carroad, P.A., C. R. Wilke, LBL-4490, 72 (1976).

3. Konkin, A.A., Z.A. Rogovin, (Moscow Textile Inst.)

Bumazh. Prdm., 28(9), 15 (1953); Chem.Abs., 48, 360C (1.954).

4. Wilke, C.R., U. Von Stockax and R.D. Yang, "Process Design Basis for Enzymatic Hydrolysis of Newsprint," AIChE Symposium Series, Volume 72, No. 158, 104 (1977). 
Published Papers

1. Wilke, C.R., U. Von Stockar and R. D. Yang, "Process Design Basis for Enzymatic Hydrolysis of Newsprint," AIChE Symposium Series, Volume 72, No. 158, 104 (1977).

2. Von Stockar, Urs, Ren Der Yang and Charles R. Wilke, "Computation of the Fraction of Induced Cells in Enzyme Induction Systems," Biotechnol. \& Bioeng., 19, 445-458 (1977).

3. Carroad, Paul and Charles R. Wilke, "Cell Growth and Catecholase Production of Polyporus versicolor in Submerged Cultures," Applied and Environmental Microbiology, 33, 836 (1977).

4. Carroad, Paul, and Charles R. Wilke, "Exponential Growth Kinetics for Polyporus versicolor and Pleurotus ostreatus in Submerged Culture," Applied and Environmental Microbiology, 33, 871 (1977).

5. Cysewski, G.R. and C.R. Wilke, "Rapid Ethanol Fermentation Using Vacuum and Cell Recycle," Biotechnol. and Bioeng. 19, 1125 (1977).

Published Reports

1. Castanon, Maria and Charles R. Wilke, "Studies on the Enzymatic Hydrolysis of Newsprint," LBL-5950 (October 1976).

2. Yamanaka, Yoshio and C. R. Wilke, "The Effect of Glucosidase on the Enzymatic Hydrolysis of Cellulose," LBL-4413 (December 1975).

3. Yamanaka, Yoshio, Paul A. Carroad, Mohammad Riaz and Charles R. Wilke, "Decomposition of Lignin and Cellobiose in Relation to the Enzymatic Hydrolysis of Cellulose," LBL-5960 (February, 1977).

4. Cysewski, Gerald R. and Charles R. Wilke, "Rapid Ethanol Fermentations Using Vacuum and Cell Recycle, "LBL 5261 (February 1977). 
Reports and papers to be published

Wilke, C.R., "Systems for Hydrolyzing Cellulose to Generate Fermentable Carbohydrates," paper presented at symposium on Bioconversion of Solar Energy at Campinas, Brazil, 1976. LBL-5275 (in press).

Carroad, Paul A. and Charles R. Wilke, "Enzymes and Microorganisms in Food Industry Waste Processing and Conversion to Useful Products," LBL-5962 (in press) (Submitted to Resource Recovery and Conversion).

Cysewski, Gerald R. and Charles R. Wilke, "Process Design and Economic Studies of Alternative Fermentation Methods to the Production of Ethanol," IBL-5363 (in press) (Submitted to Biotechnol. and Bioeng.).

Sciamanna, Aldo, Ray Frejtas and C.R. Wilke, "Composition and Utilization of Cellulose from Agricultrual Residue for Chemicals," LBL-5966.

Freitas, Ray, C.R. Wilke and Bill Long, "Procedures for Analysis of Solids and Liquors from Cellulosic Sources," LBL-5967 (in press).

Batter, Thomas R. and C.R. Wilke, "A Study of xylose to Ethanol by Fusarium Oxysporum," LBL-6351 (in press).

Wilke, C.R., "Production of Sugars and Ethanol Based on the Enzymatic Hydrolysis of Cellulose:"

Harima, Takeshi, and C.R. Wilke, "Comparison of Batch and Continuous Cellulose Hydrolysis with and without Ethanol Fermentation." Report in preparation.

Harima, Takeshi, and C.R. Wilke, "Enhancement of Enzymatic Hydrolysis of Cellulose by Coupling with Ethanol Fermentation." 


\section{Invited Lectures}

1. "The Use of Biomass as a Chemical and Energy Source, Northern California Section, American Institute of Chemical Engineering, 16 Annual One-Day Symposium, "Chemical Engineering in the Next Ten Years, April 26, 1977.

(C. R. Wilke)

2. "Bioconversion of Cellulose to Ethanol" to the Professional Development Program Chemistry/Chemical Engineering, University of California, Berkeley, August 2, 1977 (Steven Rosenberg). 


\author{
Appendix \\ CELLULOSE BIOCONVERSION AND PILOT PLANT STUDIES \\ Lawrence Berkeley Laboratory \\ Project Staff
}

\title{
Faculty Investigator
}

Charles R. Wilke, Professor of Chemical Engineering

Postdoctoral Investigators

Takeshi Harima, Biochemical Engineering, University of Pennsylvania, Ph.D. 1977.

Mohammad Riaz, Microbial Biochemistry, University of Wales, U.K. Ph.D. 1969 .

Steven Rosenberg, Bacteriology, University of California, Berkeley Ph.D. 1970 .

Ren-Der Yang, Chemical Engineering and Biochemical Engineering, University of Pennsylvania, Ph.D. 1974.

Graduate Students

Thomas Batter, Food Science and Nutrition, University of California Berkeley, B.S. 1974. M.S. Candidate

Ron Borrevik, Chemical Engineering, University of Washington, B.S. 1976. M.S. Candidate

Mary Jane Howell, Chemical Engineering, Cornell University B.S. 1976. M.S. Candidate

Steven Isaacs, Chemical Engineering, Massachusetts Institute of Technology, B.S. 1976. M.S. Candidate

Richard Lindsey, Chemical Engineering, Illinois Institute of Technology, B.S. 1976, M.S. Candidate

Shu-Yin Wei, Biostatistics, Cornell University, B.S. 1974. M.S. Candidate

Harry Wong, Chemical Engineering, Massachusetts Institute of Technology, M.S. 1973. Ph.D. Candidate 


\section{Support Staff}

Aldo Sciamanna, Chemist

Ray Freitas, Biochemist

Bill Long, Technician

Barbara Brandon

Keith Perry

Loretta Baier
M.S. in Chemistry, Univ. of San Francisco, 1952.

B.A. Biochemistry, 1974

B.S. Chemistry, 1975

Univ. of California, Berkeley

Undergraduate (Senior)

Department of Chemical Engineering University of California, Berkeley

B.A. Chemistry, 1976

Case Western University

Undergraduate (Junior)

Department of Bacteriology

University of California, Berkeley 


\section{Current Projects and Assignments}

(DPR

and

Solar) *

(DPR)

(DPR)

(Solar)

(Solar)

(DPR

and

Solar

(DPR

and

NSF )

(DPR)

(DPR, Solar and NSF)

(DPR)
Cellulase Production with cell Recycle Ren-Der Yang and Bill Long

Enzymatic Hydrolysis Kinetics

Ren-Der Yang, Jessie Wei and Richard Iindsay

Enzyme Recovery (Adsorption-Desorption)

Mohammad Riaz and Richard Lindsay

New Raw Materials Analyses and Carbohydrate Yields

Aldo Sciamanna, Ray Freitas and Bill Long

Hemicellulose Extraction and Hydrolysis

Aldos Sciamanna and Ray Freitas

Carbohydrate Fermentations--Glucose, Xylose

Takeshi Harima, Harry Wong, Tom Batter,

Barbara Brandon and Steven Rosenberg

Mixed Enzyme Development $--\mathrm{C}_{2}, \quad B-g$ lucosidase

Mohammad Riaz, Mary Jane Howell and Steven Isaacs

Chemical Lignin Removal

Aldo Sciamanna and Ronald Borrevik

Chromatographic Separations and Analysis

Ray Freitas, Takeshi Harima, Mohammad Riaz and Bill Long

Fermentation Control via $\mathrm{CO}_{2}, \mathrm{O}_{2}$ Monitoring

Takeshi Harima 


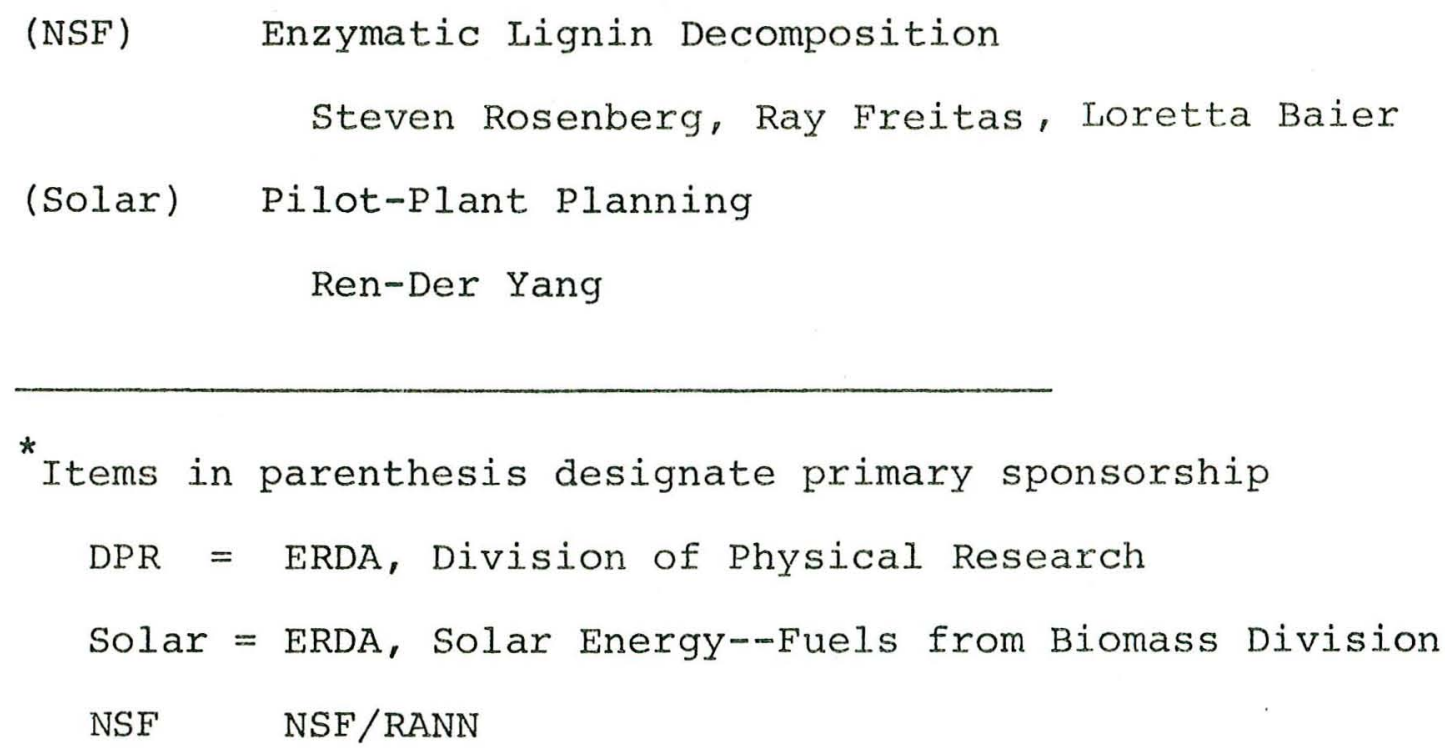




\section{Cellulose Bioconversion to Sugars and Ethanol. \\ Berkeley Program -- July, 1977}

Evaluation of Potential Raw Materials (Agricultural Residues)
(a) Analysis of composition--carbohydrates, lignin, etc.
(b) Hemicellulose extraction--dilute acid pretreatment
(c) Alkali pretreatment
(d) Enzymatic hydrolysis of original and pretreated materials

\section{Cellulase Production}

(a) Multistage fermentation with cell recycle

(b) T. viride growth model via $\mathrm{CO}_{2}$ vtilization

Hydrolysis Kinetics (T. viride cellulase)
(a) CSTR--short circuiting effects
(b) Countercurrent hydrolysis
(c) Product inhibition

Enzyme Adsorption-Desorption

(a) Adsorption of $C_{1}, C_{X}$ and $\beta$-glucosidase activities on cellulose

(b) Enzyme Fractionation by adsorption on cellulose

(c) Enzyme Desorption--effect of additives

Mixed or Supplementary Enzyme System Development
(a) B-glucosidase (NSF project)
(b) $\mathrm{C}_{2}$ complex from $\underline{T}$. koningii

Chemical Delignification Studies
(a) Glycol treatment
(b) Ethanol treatment
(c) Assessment of other potential methods

Enzymatic and Microbial Delignification

(a) Study of Phanarochaete chrysosporium (NSF project)

Cellulose and Glucose Fermentation to Ethanol

(a) Vacuum and cell recycle system development

(b) Media optimization

(c) Simultaneous enzymatic hydrolysis and fermentation

Xylose Fermentation to Ethanol

(a) Fusarium oxysporum (f. sp. lini) 
This report was done with support from the United States Energy Research and Development Administration. Any conclusions or opinions expressed in this report represent solely those of the author(s) and not necessarily those of The Regents of the University of California, the Lawrence Berkeley Laboratory or the United States Energy Research and Development Administration. 